\title{
El inventario de bienes (1531) de Guillemyn Baqua. Un apunte sobre la actividad de los escultores franceses entre la Ribera de Navarra y Aragón en el Primer Renacimiento*
}

\author{
The inventory (1531) by Guillemyn Baqua. A note on the activity of \\ French sculptors between the Ribera of Navarra and Aragón in the First \\ Renaissance \\ Jesús CRIADO MAINAR \\ Universidad de Zaragoza \\ ORCID: http://orcid.org/0000-0001-8328-1642 / jcm@unizar.es \\ DOI: http://dx.doi.org/10.18002/da.v0i19.6169
}

Recibido: $27-\mathrm{II}-2020$
Aceptado: $7-\mathrm{V}-2020$

RESUMEN: El estudio de un inventario post mortem inédito de los bienes del entallador francés Guillemín Leveque ha permitido efectuar una aproximación a la modesta realidad socioeconómica y laboral de los profesionales de la escultura de segundo rango en el contexto del Primer Renacimiento. Los datos que aporta el documento, unidos a otros ya conocidos sobre su actividad, evidencian los estrechos vínculos personales y laborales que mantuvo con la comunidad de escultores franceses establecida en el valle medio del Ebro, en particular con Esteban de Obray y Gabriel Joly.

Palabras clave: Escultura; Renacimiento; Historia social; Aragón y Navarra.

ABSTRACT: The study of the unpublished post mortem inventory of the French entallador Guillemin Leveque has allowed an approach to the modest socio-economic and labor reality of second-class sculpture professionals in the context of the first Renaissance. The information provided by the document, together with others already known about its activity, demonstrate the close personal and labor ties that he maintained with the community or French sculptors established in the middle valley of the Ebro, notably with Esteban de Obray and Gabriel Joly.

Keywords: Sculpture; Renaissance; Social History; Aragón and Navarra.

El aporte nórdico al desarrollo de la escultura española de la fase temprana del Renacimiento fue en muchos aspectos tan determinante como las novedades llegadas directamente de Italia, tanto a través de los artistas que viajaron hasta aquí como por otros cauces. Ningún territorio peninsular escapa a una vía de renovación que, poco a poco, vamos cartografiando con mayor precisión gracias a los estudios que en los últimos años han sacado a la luz valiosas contribuciones sobre los grandes nombres, pero también en relación con otros artífices que, pese a su modestia, son imprescindibles para dibujar un panorama de suficiente amplitud. Nuestros archivos están llenos de

* A la memoria de Antonio Ceruelo Caro. 
noticias sobre imagineros y entalladores llegados desde Flandes y los vecinos territorios del noroeste de Francia (Picardía y Normandía), así como de Borgoña, Lorena o Champaña, sin que tampoco falten viajeros que, como el protagonista de nuestra aportación, procedían de regiones más meridionales (en este caso, Bearne).

Este variado panorama se traduce en una realidad heterogénea y de compleja sistematización, por lo que los ensayos que aportan síntesis territoriales tienen un gran valor a la hora de establecer líneas generales ${ }^{1}$. Y también lo son aquellos que ayudan a conceder toda la relevancia que merecen a artífices que por su meritoria labor deben formar parte de la élite de la escultura del momento; en este caso, el esfuerzo por bucear en sus orígenes, fuentes figurativas y trayectoria vital puede reportar una información preciosa para una valoración ponderada de su contribución a nuestro complejo y heteróclito siglo $\mathrm{XVI}^{2}$.

El valle medio del Ebro no es una excepción y el papel de los escultores franceses en la consolidación del Primer Renacimiento fue también aquí determinante. Dentro de este ámbito territorial, la ciudad episcopal de Tarazona (Zaragoza), situada en un cruce de caminos entre Aragón, Navarra, Castilla y La Rioja, actuó durante esos años como

\footnotetext{
${ }^{1}$ Así, por ejemplo, María José Redondo Cantera, "L'apport français à la sculpture de la Renaissance en Castille. Réflexions sur le style et les matériaux", en $L a$ sculpture française du XVI siècle. Études et recherches, ed. por Marion Boudon-Machuel (París: Institut National d'Histoire de l'Art-Le bec en l'air éditions, 2011), 138149. Y también Pedro L. Echeverría Goñi, “Protagonismo de los maestros galos de la talla en la introducción y evolución del Renacimiento en Navarra", Príncipe de Viana, LXXIII, no 256 (2012), 515-548.

${ }^{2}$ Puede citarse el estudio clásico de André Turcat, Etienne Jamet alias Esteban Jamete. Sculpteur français de la Renaissance en Espagne condamné par l'Inquisition (París: Picard, 1994). Asimismo, el excelente artículo sobre el escultor Arnao de Bruselas publicado en fecha reciente por el profesor Aurelio Á. Barrón García, "Orígenes, formación y testamento del escultor renacentista Arnaut Spierinck, o Arnao de Bruselas", Santander. Estudios de Patrimonio, no 2 (2019), 65-120.
}

lugar de residencia de un nutrido grupo de artífices galos de la madera ${ }^{3}$ así como punto de destino de trabajos de otros maestros de idéntica procedencia ${ }^{4}$. El inventario post mortem y la almoneda de los bienes del entallador bearnés Guillemín Leveque es un buen ejemplo, aunque el escenario de los hechos nos conduzca, en realidad, a Tudela (Navarra), una ciudad situada a $20 \mathrm{~km}$ de Tarazona e integrada por entonces en su territorio diocesano.

\section{ANATOMÍA DE UN INVENTARIO POST MORTEM}

El 15 de febrero de 1531, el notario Juan Pérez de Añorbe redactó en Tudela un inventario post mortem con los bienes muebles y las sumas de dinero que habían pertenecido al entallador Guillemyn Baqua, ya difunto -doc. $\mathrm{n}^{\mathrm{o}} 1-^{5}$. Su protagonista era, sin duda, el Guillén Obispo, "frances natural", que un año antes, el 8 de febrero de 1530, había recibido en esa misma localidad el traspaso de la mazonería del retablo mayor de la parroquia de San Juan Bautista de Cintruénigo (Navarra) (Fig. 1), que estaba a cargo de Esteban de

\footnotetext{
${ }^{3}$ José María Sanz Artibucilla, “El maestro entallador Pierres del Fuego. Sus primeros oficiales y obras en Navarra”, Príncipe de Viana, XV (1944), 145-158; “El maestro entallador Pierres del Fuego. Tragedia familiar y últimas obras en Navarra", Príncipe de Viana, XVII (1944), 329-338; Jesús Criado Mainar, “Baltasar de Arrás (15361543) y la escultura contemporánea en el área del Moncayo", Revista del Centro de Estudios Merindad de Tudela, no 5 (1993), 71-96; Javier Ibáñez Fernández, “Sculpteurs français en Aragon au XVI ${ }^{\mathrm{e}}$ siècle: Gabriel Joly, Esteban de Obray \& Pierres del Fuego", en La sculpture française..., 135-137.
}

${ }^{4}$ Jesús Criado Mainar, "Las artes plásticas del Primer Renacimiento en Tarazona (Zaragoza). El tránsito del moderno al romano", Tvriaso, X, II (1992), 414-415, y 436-437, doc. 12 [sepulcro del secretario Pedro Quintana en la iglesia de San Francisco]; Jesús Criado Mainar, "El Renacimiento en la Catedral", en La Catedral de Santa María de la Huerta de Tarazona (Zaragoza: Diputación de Zaragoza, 2013), 160-161 [retablo de la Visitación].

\footnotetext{
${ }^{5}$ Agradezco a la Dra. María Josefa Tarifa Castilla, Profesora Titular de la Universidad de Zaragoza, su generosidad por facilitarme este documento.
} 


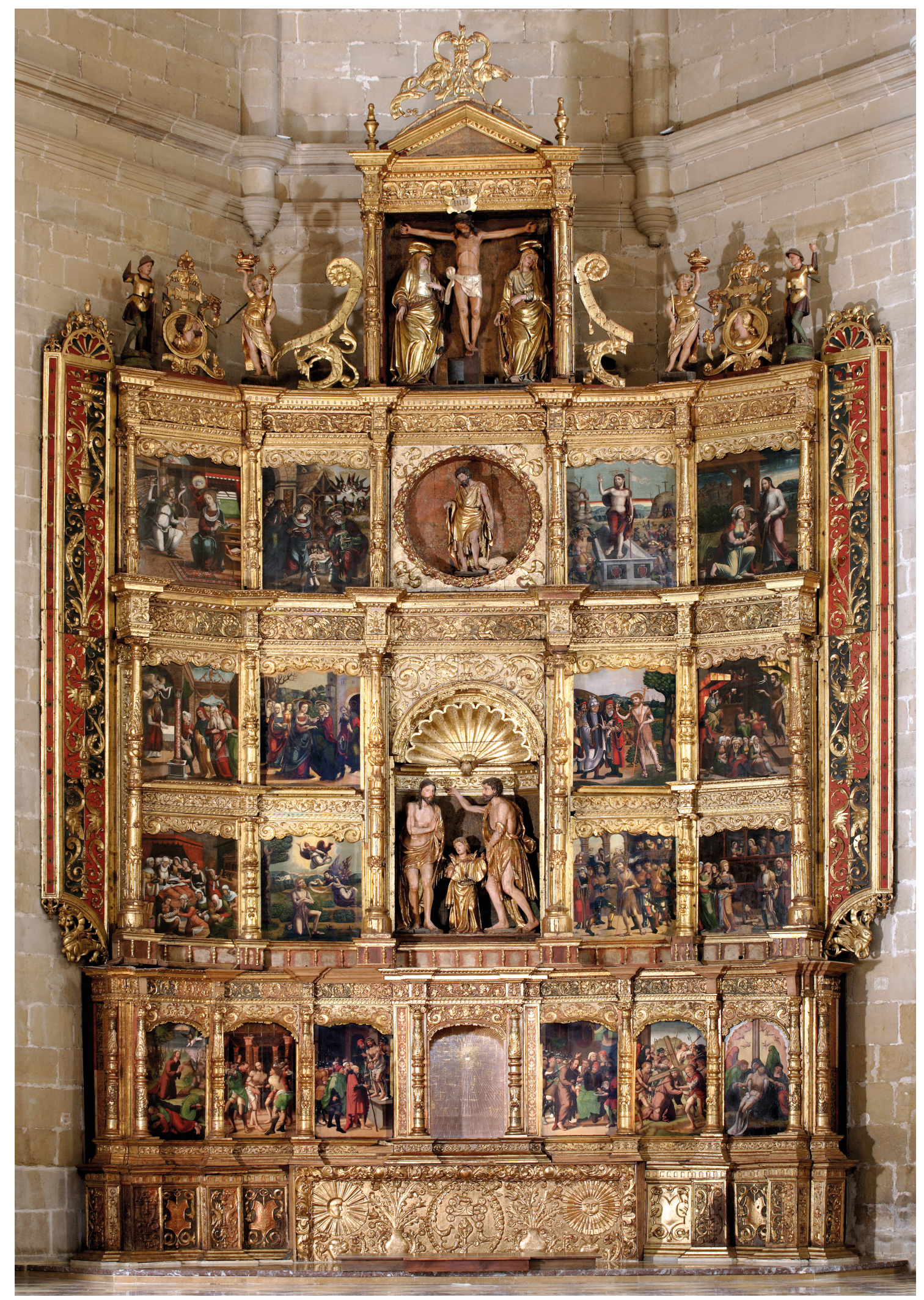

- Fig. 1. Esteban de Obray y Guillemin Leveque (mazonería); Gabriel Joly (atribuido a, imágenes); Pedro de Ponte y ¿Juan Giner? (pintura). Retablo mayor de San Juan Bautista de Cintruénigo. A partir de 1525. Foto Selenio. 
Obray $^{6}$. La aparente distancia entre su apellido y la versión del mismo que ofrece el fedatario público se acorta si recordamos que en otra oportunidad ${ }^{7}$ ya propusimos identificar a Guillén Obispo con el Guillemín Leveque ${ }^{8}$ que entre 1528 y 1529 trabajó en Zaragoza para Damián Forment en la mazonería del retablo de la Resurrección para la capilla de Jaime Conchillos, obispo de Lérida, en Santa María la Mayor de dicha ciudad 9 .

El recuento de bienes se efectuó a instancias del licenciado Juan de Corella, teniente de alcalde de Luis Díaz de Armendáriz, alcalde y juez ordinario de la ciudad. Estaban depositados en las casas de Antón de Alzate, en la parroquia de San Jorge, pero como este último también había muerto para entonces se hallaron en poder de su viuda. La escritura señala a fray Juan Diego de Imiguitu, guardián de San Francisco, como autor de un primer listado con las pertenencias del entallador que el religioso había llevado a cabo en presencia del ya citado Antón de Alzate, de Olivier de Santribuén -calificado asimismo de entallador y criado de Guillemín Leveque- y de Juan de Baigorri.

Los enseres del finado ${ }^{10}$ reflejan una situación socioeconómica modesta, equipara-

${ }^{6}$ José R. Castro, Cuadernos de Arte navarro. B) Escultura (Pamplona: Institución Príncipe de Viana, 1949), 25-26, doc. II.

${ }^{7}$ Jesús Criado Mainar, "Relaciones entre la Ribera de Navarra y Aragón durante la época del Renacimiento", Cuadernos de la Cátedra de Patrimonio y Arte Navarro, no 3 (2008), 218

${ }^{8}$ Recuérdese que el término usado en lengua francesa para "obispo" es évêque.

${ }^{9}$ Manuel Abizanda Broto, Documentos para la historia artística y literaria de Argón procedentes del Archivo de Protocolos. Siglo XVI (Zaragoza: Patronato Villahermosa-Guaqui, 1917), T. II, 216-217. Sobre este retablo, Carmen Morte García, Damián Forment, escultor del Renacimiento (Zaragoza: Caja Inmaculada, 2009), 255-259. Sobre la capilla, Olga Hycka Espinosa, Santa María la Mayor y del Pilar de Zaragoza. Evolución histórica del templo colegial (Zaragoza: Institución "Fernando el Católico", 2018), 371-394.

${ }^{10}$ Que según precisan varias actas notariales zaragozanas no sabía escribir. ble a la de otros artífices giróvagos del siglo XVI sin medios para poner en marcha un taller estable y que fueron probando suerte por distintos lugares mientras servían a otros colegas, entre los que no faltaban profesionales franceses de la madera ${ }^{11}$. La parte fundamental está integrada por su atuendo: un jubón morado de raso ${ }^{12}$, un sayo de Contray $^{13}$ con las mangas picadas calificado de "raydo" -viejo-, una capa de Contray con "trepas" de terciopelo ${ }^{14}$, unas calzas asimismo de Contray, una capa de "pardillo"15 con otro sayo -que ya se habían vendido en 12 florines-, una gorra negra, un guante de malla, un puñal dorado, así como un broquel y un casco. Se encontró, además, un albarán por diversas sumas que totalizaban 37 ducados y 10 reales castellanos.

La viuda de Alzate guardaba junto a estas prendas el paupérrimo utillaje profesional del artífice, compuesto por "onze imagines de piecas de plomo", "doze piecas de fierro con sus mangos de fusta de su oficio, y un martillo, y unas lecas ${ }^{16}$ y dos barrenicas". El escribano indicó que los bienes esta-

${ }^{11}$ Para el ámbito navarro en el que se enmarca la documentación que estudiamos, Echeverría Goñi, “Protagonismo de los maestros galos...", 515-548.

${ }^{12}$ Para el D.R.A.E., un jubón es una "vestidura que cubre desde los hombros hasta la cintura, ceñida y ajustada al cuerpo".

${ }^{13}$ Según el D.R.A.E., un sayo es una "prenda de vestir holgada y sin botones que cubría el cuerpo hasta la rodilla". Los tejidos de "Contray", es decir, manufacturados en la ciudad flamenca de Courtrai, podían ser de paño fino o de tela blanca de lienzo. En Rosa María Dávila Corona, Montserrat Durán Pujol y Máximo García Fernández, Diccionario histórico de telas y tejidos (Salamanca: Junta de Castilla y León, 2004), 64.

${ }^{14}$ Trepa: "Adorno que se pone al borde de un vestido siguiendo y dando la vuelta a todo su contorno, realizado por la técnica de agujereado u horadado". En María Ángeles González Mena, Colección pedagógico textil de la Universidad Complutense de Madrid. Estudio e inventario (Madrid: Editorial Complutense, 1994), Glosario, p. 20.

${ }^{15}$ Indica el D.R.A.E. que el paño pardillo es "el más tosco, grueso y basto que se hace, de color pardo, sin tinte, de que se viste la gente humilde y pobre".

${ }^{16}$ Quizás unas leznas. 
ban en manos de "mase Steban", calificado poco después de entallador, lo que permite identificarlo con el mazonero normando Esteban de Obray, afincado en Tudela desde 1519 aunque residente en ese momento en Calatayud (Zaragoza). El texto señala, por último, que también se hizo cargo de "catorze fresos del oficio, un[a] escofia [y] mas una espada".

Salvo la primera entrada, con "onze imagines de piecas de plomo", que no resulta fácil interpretar pero que tiene correspondencia con objetos localizados en el taller del pintor salmantino Adiosdado de Olivares ${ }^{17}$, el resto alude a herramientas del arte de la talla de madera. Así, las "doze piecas de fierro con sus mangos de fusta de su oficio" eran, con seguridad, gubias de diferentes calibres. A ellas se sumaban un martillo -quizás un mazo de talla- y unas leznas o punzones para marcar sobre las planchas de madera, imprescindibles a la hora de trasladar dibujos. Había, además, dos "barrenicas" para taladrar y una "escofia" o escofina para lijar.

Cuesta esfuerzo imaginar que con tan menguado equipo Guillemín Leveque y su ayudante, Olivier Santribuén, pudieran acometer proyectos como el del retablo de Cintruénigo. Sea como fuere, nos encontramos frente a una realidad modesta, alejada de la que traslucen los inventarios de grandes talleres del momento como el del escultor Felipe Bigany $(+1543)^{18}$ o incluso otros más

\footnotetext{
${ }^{17}$ Que en 1572 tenía en su taller diferentes elementos anatómicos de metal, entre ellos un rostro "de anatomía", cinco piernas y brazos o un mascarón, así como "una figura de metal". La entrada que más se aproxima a la nuestra describe "çinco cuerpos de hombre pequeños y medianos de metal". En Felipe Pereda, "Adiosdado de Olivares, o la dignidad de las artes mecánicas", en El modelo italiano en las artes plásticas de la Península Ibérica durante el Renacimiento, coord. por María José Redondo Cantera (Valladolid: Universidad de Valladolid, 2004), 306.

18 José Domínguez Bordona, "El escultor Felipe Vigarny o de Borgoña (datos inéditos)", BSEE, XXII (1914), 263-266. Su estudio en Isabel del Río de la Hoz, El escultor Felipe Bigarny (h. 1470-1542) (Salamanca: Junta de Castilla y León, 2001), 342-348.
}

tardíos -y también más humildes- como los de los ensambladores Guillomo Peral $(+1591)^{19}$ o Juan de Ribera $(+1594)^{20}$. Después nos ocuparemos de los "catorze fresos del oficio" citados en el texto.

El documento refiere que fray Diego de Imiguitu dio a Antón de Alzate 16 ducados viejos en moneda, hallados junto a los enseres de maestre Guillemín, con los que se sufragaron los gastos del sepelio -en los que no nos detendremos- y se pudo entregar un ducado a Olivier Santribuén "para que fuese a Calatayut [a buscar] a maestre Esteban, entallador". Todo ello ascendió a 3 ducados $45 \frac{1}{2}$ tarjas, por lo que quedó un remanente de 12 ducados $4 \frac{1}{2}$ tarjas.

Esta primera parte concluye con una diligencia en la que se indica que tanto la "demasia" -los 12 ducados 4 1/2 tarjas- como los bienes muebles inventariados fueron encomendados otra vez "a maestre Esteban, entallador, vecino de Tudela" en presencia del fraile. Los dos suscribieron el documento de su propia mano con asistencia de Santribuén, quien si no hizo lo propio fue, sin duda, por no saber escribir. Tras la rúbrica notarial se añadió un último apunte expresando "que debe mase Forment, vezino de Caragoca, al dicho mase Guillemin de Baqua, defunto, cuarenta libras jaquesas".

\footnotetext{
19 Estudiado por Manuel Arias Martínez, “Testamento, inventario y almoneda del ensamblador normando Guillomo Peral (†1591): datos para la definición profesional", Astorica, no 28 (2009), 227-253.

Para la morfología de un taller renacentista de escultura, Jesús María Parrado del Olmo, Talleres escultóricos del siglo XVI en Castilla y León. Arte como idea. Arte como empresa comercial (Valladolid: Universidad de Valladolid, 2002), 65-95.

${ }^{20}$ Que además del utillaje de entallador incluye herramientas de carpintería y ensamblaje. En Ángel San Vicente, Lucidario de Bellas Artes en Zaragoza: 15451599 (Zaragoza: Real Sociedad Económica Aragonesa de Amigos del País, 1991), 498, doc. 413. Su análisis en Ángel Hernansanz Merlo, "Materiales y técnicas de la escultura", en La escultura del Renacimiento en Aragón, coord. por María Isabel Álvaro Zamora y Gonzalo M. Borrás Gualis (Zaragoza: Museo "Camón Aznar", 1993), 59-61.
} 
La segunda parte de la escritura recoge la almoneda de los bienes, efectuada el 5 de marzo. Como detallan los apuntes, Pedro el tundidor adquirió un par de calzas negras por 28 tarjas, las herramientas profesionales por una suma misérrima de 54 tarjas y la capa guarnecida por 12 florines. El propio notario se quedó con el sayo por 21 reales navarros. Por otra parte, el mozo de Jaime Tornamira -cuyo nombre no consta- remató el jubón de raso por $91 / 2$ tarjas, el puñal por 30 tarjas, la gorra por 21 tarjas, la escofina por 5 tarjas y una caja por 15 tarjas. La espada fue para Juan Castillo, que pagó 42 tarjas por ella, mientras que el casco se adjudicó en 6 tarjas a un comprador anónimo.

Apenas cinco días después de contabilizarse el producto de las ventas ${ }^{21}$, el 10 de marzo se estipuló que la almoneda, "a menos de las deudas que por los albaranes se le deben"22, había reportado 50 florines 10 groses y 8 cornados, que se entregaron en depósito a Esteban de Obray. La cuenta debía incrementarse con "el albaran de los trenta y siete ducados biejos y un real castellano que debe mase Gabriel, ymaginario, vezino de Caragoca" -el escultor Gabriel Joly-; se trata, pues, del albarán citado al comienzo, tras el listado de la ropa, aunque allí no figure la identidad del deudor. Y también era preciso añadir los 16 ducados hallados entre las pertenencias del entallador, de los que ya se había hecho mención ${ }^{23}$.

\footnotetext{
${ }^{21}$ La liquidación no recoge la venta de las "onze imagynes de piecas de plomo".

${ }^{22}$ La comanda de 40 libras jaquesas que adeudaba Damián Forment.

${ }^{23}$ Como se recordará, de esta suma se habían detraído 3 ducados 45 1/2 tarjas, gastados en el funeral y en el viaje de maestre Olivier a Calatayud para informar a Obray de la muerte de Leveque, para lo que se le entregó 1 ducado viejo.
}

ENTRE TUDELA, CALATAYUD Y CINTRUÉNIGO. GUILLEMÍN LEVEQUE, ESTEBAN DE OBRAY Y GABRIEL JOLY: UNA CERTEZA Y UNA HIPÓTESIS

Antes de profundizar en la información que aporta el inventario de bienes debemos subrayar la posición preeminente que en él se otorga a Esteban de Obray (doc. 1519†1551) $)^{24}$, a quien Olivier Santribuén, criado del causante, fue a buscar a Calatayud y que más tarde recibió en depósito el producto de la liquidación de sus menguados enseres, sus créditos y los "catorze fresos del oficio" que dejó para su custodia. Todo ello nos sitúa en el horizonte de la realización del retablo de la parroquia de San Juan Bautista de Cintruénigo, un conjunto de considerables dimensiones a cargo del pintor Pedro de Ponte.

El pintor toresano afincado en Zaragoza cedió su arquitectura a Obray el 1 de diciembre de 1525 en virtud de una capitulación rubricada en la capital aragonesa, en la que se advierte que las imágenes no quedaban bajo su responsabilidad y que "maestre Gabriel" actuaría como veedor ${ }^{25}$. Para entonces el maestro Esteban ya había completado la sillería tardogótica del coro de Santa María de Tudela (h. 1514/1517-1522) ${ }^{26}$ y, sin duda, su

\footnotetext{
${ }^{24}$ Su biografía en Raquel Serrano Gracia, “Obray, Esteban de", en La Escultura..., 256-260.
}

${ }^{25}$ Abizanda Broto, Documentos..., T. II, 35-36. Una nueva transcripción en Carmen Morte García, "Estudio histórico-artístico de una obra renacentista", en Carmen Morte García y Javier Latorre Zubiri, El retablo mayor de la parroquia de San Juan Bautista de Cintruénigo. Historia y conservación (Pamplona: Gobierno de Navarra, 2009), 17-18.

${ }^{26}$ Las noticias que colocan al frente de la obra a "maestre Esteban, maestro del coro", en Castro, Cuadernos..., 9-14. Sobre este conjunto María Concepción García Gainza, "La introducción del Renacimiento. Un brillante promotor y un mecenas", en La catedral de Tudela (Pamplona: Gobierno de Navarra, 2006) 270-274; María Concepción García Gainza, "La sillería del coro", Tudela. El legado de una catedral (Pamplona: Fundación para la Conservación del Patrimonio Histórico de Navarra, 2006), 219-220. 


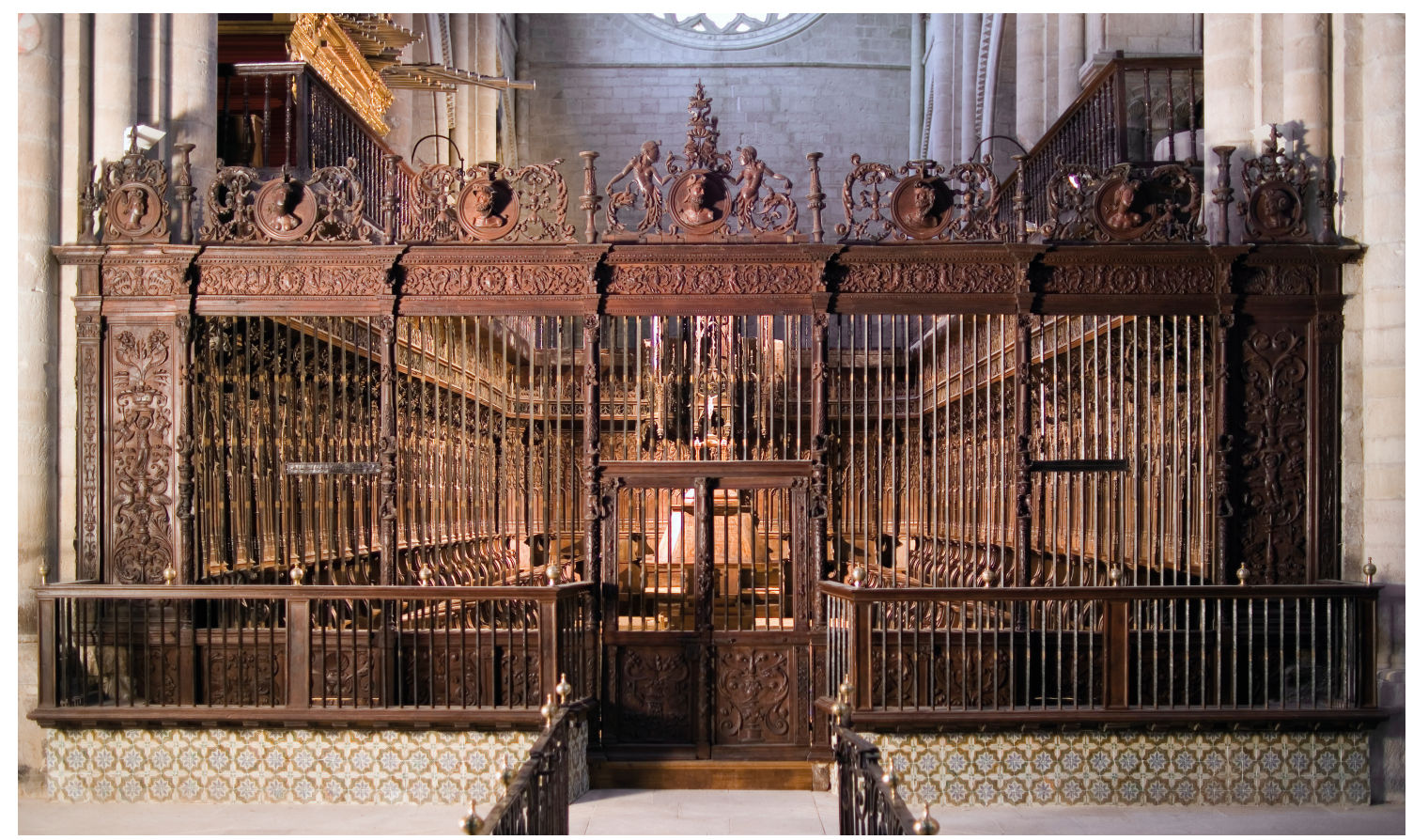

- Fig. 2. Esteban de Obray (atribuido a). Reja del coro de Santa María de Tudela. Hacia 1522-1525. Foto Selenio.

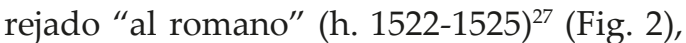
y como hemos propuesto en oportunidades anteriores, es probable que también hubiera hecho el retablo de la capilla de la Visitación (h. 1523-1525) de la Seo de Tarazona ${ }^{28}$, lo que justificaría su presencia en esta ciudad en junio de 1525, donde tomó como oficial de talla a Ramón de Lorán, de Troyes (Champaña), para tres años y medio ${ }^{29}$.

Pero lo cierto es que cuando Obray asumió en diciembre de 1525 la mazonería del retablo cirbonero ya había contratado en $\mathrm{Ca}$ latayud, junto al "maestro de canteria" Juan de Talavera, la portada de alabastro de la colegiata de Santa María (1525-h. 1528) (Fig. 3) mediante la firma de una meticulosa capi-

${ }^{27}$ Sobre cuya realización no se ha podido localizar dato documental alguno, pero que se atiene al repertorio de Obray. Véase García Gainza, "La introducción...", 274-275; Criado Mainar, "Relaciones...", 215216; y Morte García, "Estudio histórico-artístico...", 32-37.

${ }^{28}$ Criado Mainar, "Relaciones...", 215; Criado Mainar, “El Renacimiento...", 160-161.

${ }^{29}$ Criado Mainar, “Relaciones...", 216, n. 10. tulación el 5 de febrero ${ }^{30}$. No parece que el entallador normando desplazara de inmediato su casa y familia a Calatayud, pues en febrero de 1526 se esperaba su presencia ${ }^{31} \mathrm{y}$ una noticia tardía, de 1528, nos informa del bautizo de su hijo Diego en Tudela ${ }^{32}$, pero lo lógico es que en algún momento tomara la decisión de establecerse allí, con mayor o menor continuidad, hasta $1532^{33}$, pues en esos años efectuó otros trabajos en territorio bilbilitano: los retablos de Aniñón (h. 1525-

${ }^{30}$ Salvador Amada Sanz, "Estudio histórico-artístico de la portada y puertas de la Colegiata de Sta. María de Calatayud", BSEE, LI (1947), 177-209.

${ }^{31}$ Amada Sanz, "Estudio histórico-artístico...", 206, doc. 5. Aún no debía residir, pues, en la Ciudad del Jalón.

${ }^{32}$ Castro, Cuadernos..., 10.

${ }^{33}$ La cronología de la etapa bilbilitana de Obray en Jesús Criado Mainar y Olga Cantos Martínez, El retablo mayor de Santa María de Olvés. Las claves del Renacimiento en la Comarca de la Comunidad de Calatayud (Calatayud: Centro de Estudios Bilbilitanos de la Institución "Fernando el Católico", 2018), 29-31. Varios documentos de 1530, 1531 y 1532, otorgados fuera de la Ciudad del Jalón, lo califican de "casaestante", "habitante" o "vezino" de Calatayud. 
1530) ${ }^{34}$ y Olvés (h. 1530-1532) , $^{35}$ sobre cuya realización carecemos de datos, y una sepultura de alabastro (1529) -desaparecida- para el secretario real Juan Ruiz de Calcena y su esposa, Catalina de Urriés, destinada a Santa Clara de Calatayud ${ }^{36}$.

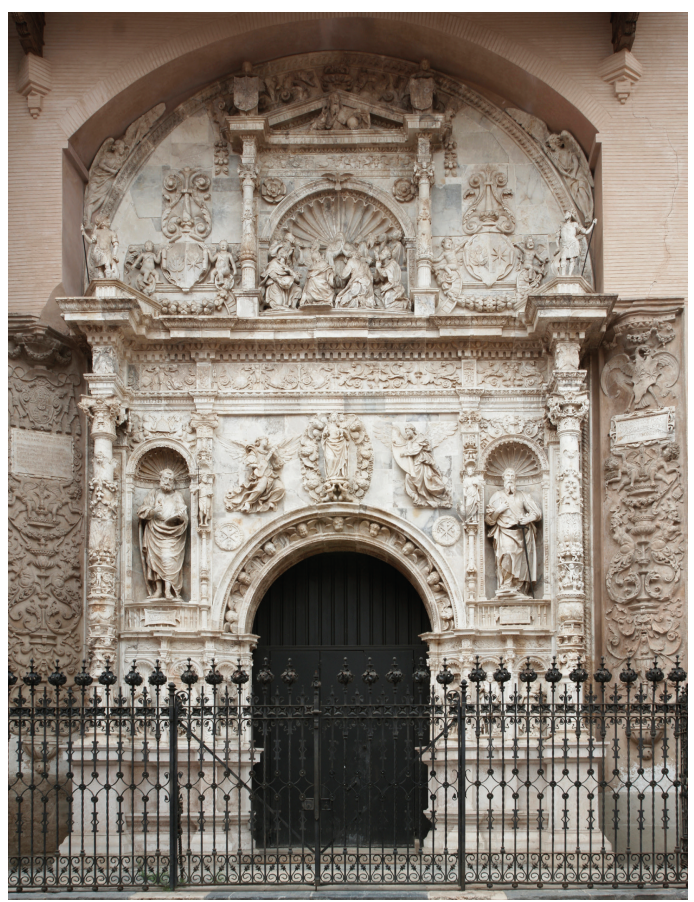

- Fig. 3. Esteban de Obray y Juan de Talavera. Portada de Santa María de Calatayud. 15251528. Foto Aurelio Á. Barrón.

A buen seguro, los compromisos bilbilitanos impidieron a Esteban de Obray afrontar personalmente la materialización de la arquitectura del retablo de Cintruénigo, que

${ }^{34}$ Raquel Serrano Gracia, "El retablo mayor de Aniñón”, Documentos y notas. Armantes, I (1994), 5-47.

${ }^{35}$ Jesús Criado Mainar, El Renacimiento en la Comarca de la Comunidad de Calatayud. Pintura y escultura (Calatayud: Centro de Estudios Bilbilitanos de la Institución "Fernando el Católico" y Comarca Comunidad de Calatayud, 2008), 79-81; Criado Mainar y Cantos Martínez, El retablo..., pp. 45-92.

${ }^{36}$ María Luisa Miñana Rodrigo et al., "Aportaciones al estudio de la obra de Esteban de Obray en Calatayud", en Segundo Encuentro de Estudios Bilbilitanos. Actas (Calatayud: Centro de Estudios Bilbilitanos de la Institución "Fernando el Católico", 1990), T. I, 387-395, con una primera y muy valiosa contribución a la etapa bilbilitana del maestro. poco debió progresar entre 1525, cuando Pedro de Ponte le confió su confección "en blanco", y febrero de 1530, momento en que, tras presentar como garante ante el concejo al canónigo Miguel de Baigorri, traspasó el encargo a Leveque ${ }^{37}$. Además, apenas unos meses después moriría el pintor tras hacer testamento en Olite (Navarra) el 7 de abril de 1530, donde tenía a su cargo el retablo titular de Santa María la Real ${ }^{38}$.

Para entonces maestre Guillemín ya había demostrado su capacidad en el retablo de la capilla del obispo de Lérida, en Santa María la Mayor de Zaragoza (1527-1529), una obra muy importante -por desgracia, desaparecida- en la que se responsabilizó de una buena parte de la mazonería, que era de madera, mientras Damián Forment (doc. 1495-11540) se reservaba las esculturas, en alabastro. Para ello se firmó una capitulación el 8 de julio de 1528, imponiéndose al francés un plazo de cuatro meses para la conclusión de su parte con la comparecencia como testigos de los imagineros Gabriel Joly y Miguel Peñaranda ${ }^{39}$. Leveque no recibió las 90 libras pactadas hasta quince meses después, el 18 de octubre de $1529^{40}$, obligándose Forment

${ }^{37}$ El 23-VI-1529 Obray facultó a Miguel de Baigorri, canónigo de Santa María de Tudela, para que renegociara con el pintor su parte en el retablo (Castro, Cuadernos..., 18, n. 22). El 7-II-1530 suscribió la carta de fianzas (Castro, Cuadernos..., 18, n. 23; transcrita en Morte García, "Estudio histórico-artístico...", 19), un día antes del traspaso a Leveque el 8-II-1530.

${ }^{38}$ Consta como fallecido en septiembre de 1530. En Carmen Morte García, "Historia", en Carmen Morte García, Javier Latorre Zubiri y Clara Fernández-Ladreda Aguadé, El retablo mayor de la iglesia de Santa María la Real de Olite. Historia y conservación (Pamplona: Gobierno de Navarra, 2007), 27.

En este caso el retablo sí quedó concluido. Sin embargo, a la muerte del pintor en Cintruénigo tan sólo debía estar en pie el banco o una parte del mismo, pues es la zona donde se ubican las únicas pinturas que le corresponden.

${ }^{39}$ Abizanda Broto, Documentos..., T. II, 216-217.

${ }^{40}$ Menciona el documento Ana I. Souto Silva, "Biografía del escultor Damián Forment", El retablo mayor de la Basílica de Nuestra Señora del Pilar de Zaragoza (Zaragoza: Fundación Nueva Empresa y Gobierno de Aragón, 
entonces en una comanda de 756 sueldos en su favor ${ }^{41}$ tras la que han de ocultarse demasías no contempladas en el contrato $u$ otros trabajos. Nótese que esta suma casi coincide con las 40 libras jaquesas (800 sueldos) que, según el inventario, le adeudaba el levantino.

A tenor de los datos de que disponemos, Guillemín Leveque debió de trabajar en Tudela en la confección de la arquitectura del retablo de Citruénigo entre el 8 de febrero de 1530 y un tiempo antes, difícil de precisar, del 15 de febrero de 1531. Esto quiere decir que una parte significativa de su mazonería (Figs. 4 y 5) debe corresponderle y que los "catorze fresos del oficio" que estaban en su poder cuando le sobrevino la muerte tenían como destino más plausible la máquina cirbonera, casi con absoluta seguridad para su cuerpo y ático, donde se contabilizan quince ${ }^{42}$.

La segunda información relevante que aporta el inventario es la deuda de $37 \mathrm{du}$ cados viejos y 1 real castellano que Gabriel Joly (doc. 1514-†1538) había contraído con Leveque. No hay duda, pues, de que estos dos profesionales galos mantuvieron contactos laborales, pero es probable que también personales, pues así parece deducirse del hecho de que Joly actuara como testigo en la subcontrata de la mazonería del retablo del obispo de Lérida. El que el otro testigo, el imaginero Miguel Peñaranda (doc. 1517-†1547), fuera un antiguo discípulo de Forment refuerza la hipótesis de que la presencia de Joly -asimismo, antiguo colaborador de Forment- obedecía a la necesidad de avalar a su compatriota.

1995), LII, n. 184. Transcrito en Morte García, Damián Forment..., ap. doc., 327, doc. 308.

${ }^{41}$ Citada por Souto Silva, "Biografía...", LII, n. 184. Su transcripción en Morte García, Damián Forment..., ap. doc., 328, doc. 309. A continuación, Leveque constituyó procuradores para cancelar la deuda a Joly y Peñaranda.

${ }^{42}$ Según la propuesta que efectuamos en Criado Mainar, “Relaciones...", 219.

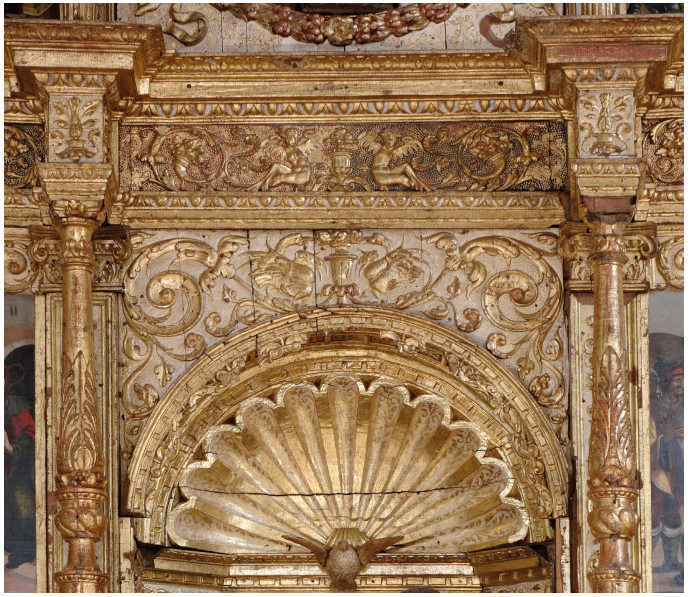

- Fig. 4. Guillemin Leveque. Retablo mayor de San Juan Bautista de Cintruénigo, remate de la hornacina titular. 1530-1531. Foto Selenio.

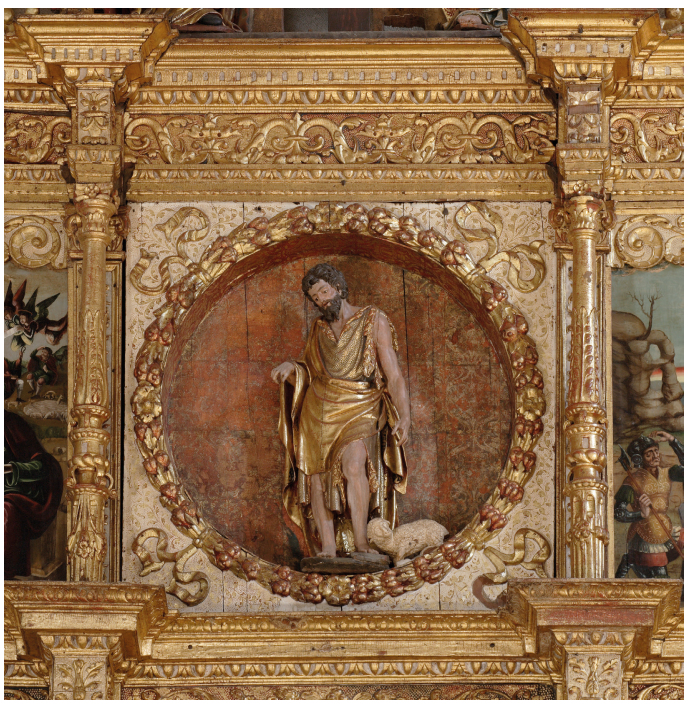

- Fig. 5. Guillemin Leveque y Gabriel Joly (atribuido a). Retablo mayor de San Juan Bautista de Cintruénigo, óculo con San Juan Bautista. 1530-1531. Foto Selenio.

Las esculturas del retablo de Cintruénigo han sido puestas en relación con las gubias de Joly a excepción del Crucificado del Calvario, de fecha anterior, y no sin reparos en lo que concierne al grupo titular ${ }^{43}$. Es evidente que su realización no competía a Leveque, que tan sólo figura en una ocasión como “imaginario" y debía carecer de la cualificación requerida para efectuar trabajos de esa

${ }^{43}$ Morte García, "Estudio histórico-artístico...", 60 y $62-65$. 


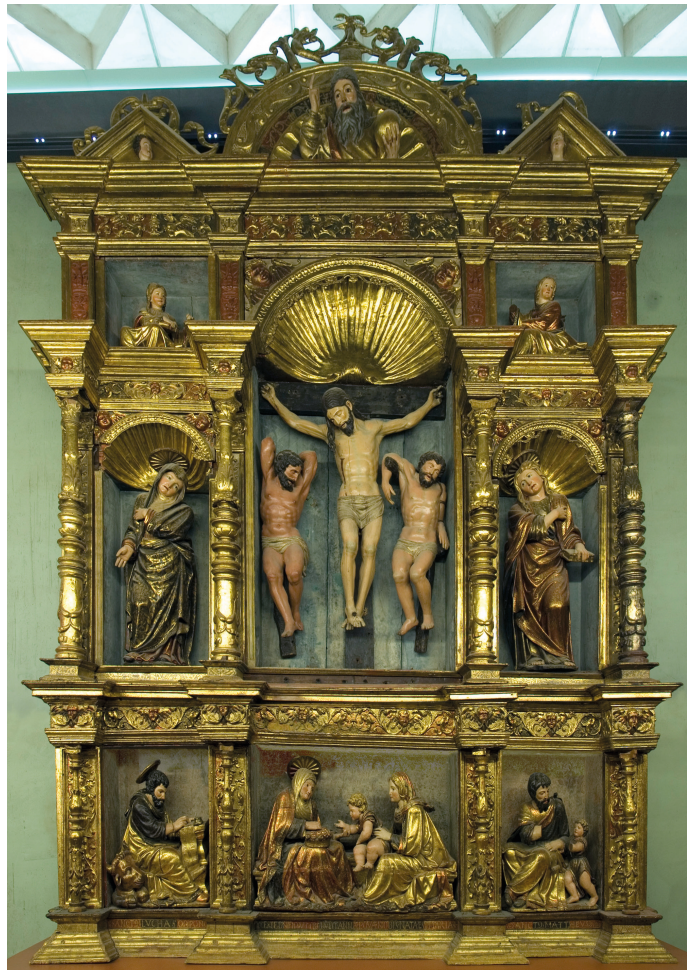

- Fig. 6. Guillemin Leveque y Gabriel Joly (atribuido a). Retablo del Calvario del Museo del Palacio Decanal de Tudela. Hacia 1529-1531. Foto Rafael Lapuente.

naturaleza. La deuda que el picardo había contraído con nuestro entallador debe derivar, pues, de otra empresa.

El Museo del Palacio Decanal de Tudela custodia un retablo escultórico del Primer Renacimiento, dedicado al Calvario (Fig. 6) y procedente de la parroquia de San Nicolás, que en otro lugar consideramos fruto de la cooperación entre Obray y Joly ${ }^{44}$. Valorando las nuevas informaciones que suministra el inventario de Leveque, no hay que descartar la posibilidad de que este último colaborara en el retablo tudelano a ruegos del imaginero picardo en una fecha comprendida entre la finalización de sus trabajos para Forment en octubre de 1529 y su incorporación a los del retablo de Cintruénigo en febrero de 1530. La hipótesis de que Leveque estuviera

${ }^{44}$ Criado Mainar, "Relaciones...", 219-220; Jesús Criado Mainar, "El retablo del Crucificado del Museo del Palacio Decanal de Tudela", Cátedra de Patrimonio y Arte Navarro. Universidad de Navarra. Memoria 2011 (Pamplona: Universidad de Navarra, 2011), 269-272.

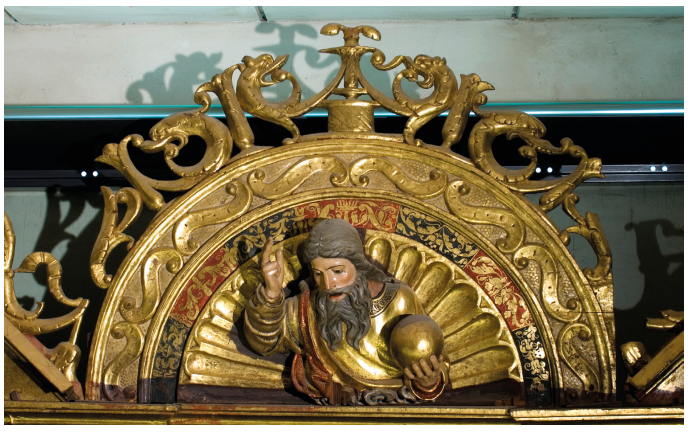

- Fig. 7. Guillemin Leveque y Gabriel Joly (atribuido a). Retablo del Calvario del Museo del Palacio Decanal de Tudela, remate de la calle central. Hacia 1529-1531. Foto Rafael Lapuente.

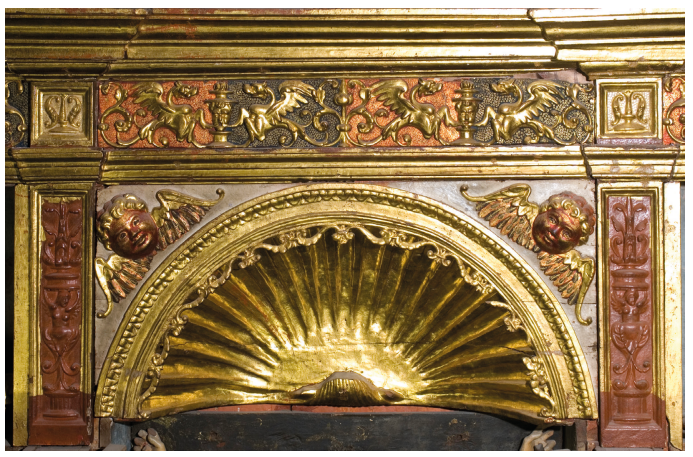

- Fig. 8. Guillemin Leveque y Gabriel Joly (atribuido a). Retablo del Calvario del Museo del Palacio Decanal de Tudela, remate de la hornacina titular. Hacia 1529-1531. Foto Rafael Lapuente.

empleado en la capital de la Ribera navarra ya en los últimos meses de 1529 -el acuerdo de Cintruénigo lo califica de "residente de presente en la dicha ciudad de Tudela"- explicaría por qué recurrió Obray a él.

Si bien es cierto que el repertorio ornamental desplegado en los frisos de estos dos retablos no es idéntico (Figs. 7 y 8), tanto su concepción plástica como su delicada técnica de ejecución están próximas y no sería extraño que tras todos ellos estuvieran las gubias de Leveque. Estas coincidencias también pueden extenderse a otros detalles de sus arquitecturas, que presentan características formales bastante similares. 
GUILLEMÍN LEVEQUE Y LAS REDES DE ESCULTORES FRANCESES EN EL PRIMER RENACIMIENTO ARAGONÉS

Hace ya algunos años un estudio colectivo llamó la atención sobre las relaciones que pueden establecerse entre la obra de algunos de los más destacados escultores franceses activos en la Península Ibérica durante el Primer Renacimiento ${ }^{45}$. Gabriel Joly, uno de los artífices citados en la testamentaría de Guillemín Leveque, sirve de eje vertebrador al ensayo, que propone posibles nexos entre su obra y la de su colega borgoñón afincado en Burgos Felipe Bigarny (act. 1498-†1543), pero asimismo con la del lorenés Nicolau Chanterene (act. 1511-1554) -que en 1528 se desplazó a Aragón para adquirir cincuenta carretadas de alabastro- ${ }^{46}$, el normando João de Ruão (act. 1526-†1580) y el enigmático Filipe Hodart (act. 1530-1535), los tres residentes en Portugal. Las coincidencias que se advierten en su respectiva labor de creación artística serían consecuencia de su común formación en los talleres del norte de Francia, una zona que asimiló en fecha temprana tanto los modelos figurativos como los repertorios ornamentales del Renacimiento italiano.

Lo que conviene reseñar ahora es que el estudio incide, además, en los contactos profesionales que los escultores franceses

\footnotetext{
${ }^{45}$ Raquel Serrano et al., "Gabriel Joly y la corriente escultórica francesa", en Actas del V Coloquio de Arte Aragonés (Zaragoza: D.G.A., 1989), 113-128.

${ }^{46}$ Abizanda Broto, Documentos..., 1915, T. I, 156. Aunque el archivero zaragozano no lo señala, Raquel Serrano y los otros autores del trabajo citado indicaron que Joly asistió como testigo a esa compra de alabastro en Gelsa (Zaragoza).

El material estaba destinado al retablo del monasterio jerónimo de Nuestra Señora de Pena, en Sintra. Véase Fernando Jorge Artur Grilo, “Nicolau Chanterene e a influência italiana na escultura do Renascimento em Portugal. Fontes e práticas artísticas", en El modelo italiano..., 400-414; Pedro Flor, "Gelsa e Sintra: relacões artísticas entre Aragão e Portugal no tempo do Renascimento", en El alabastro. Usos artísticos y procedencia del material, coord. por Carmen Morte García (Zaragoza: Prensas Universitarias de Zaragoza, 2018), 201-220.
}

afincados en Aragón mantuvieron entre sí, interesándose por los de Joly con Obray, pues como hemos visto fue el segundo quien cedió a Leveque la mazonería del retablo de Cintruénigo. Sus diferentes perfiles -Joly era imaginero y Obray entallador-facilitaban $a$ priori esa colaboración, que resultaría evidente en las obras comunes que se les atribuyen, en especial los retablos de Aniñón (Fig. 9) y Olvés, pero lo cierto es que la documentación no la corrobora salvo de forma indirecta para Cintruénigo.

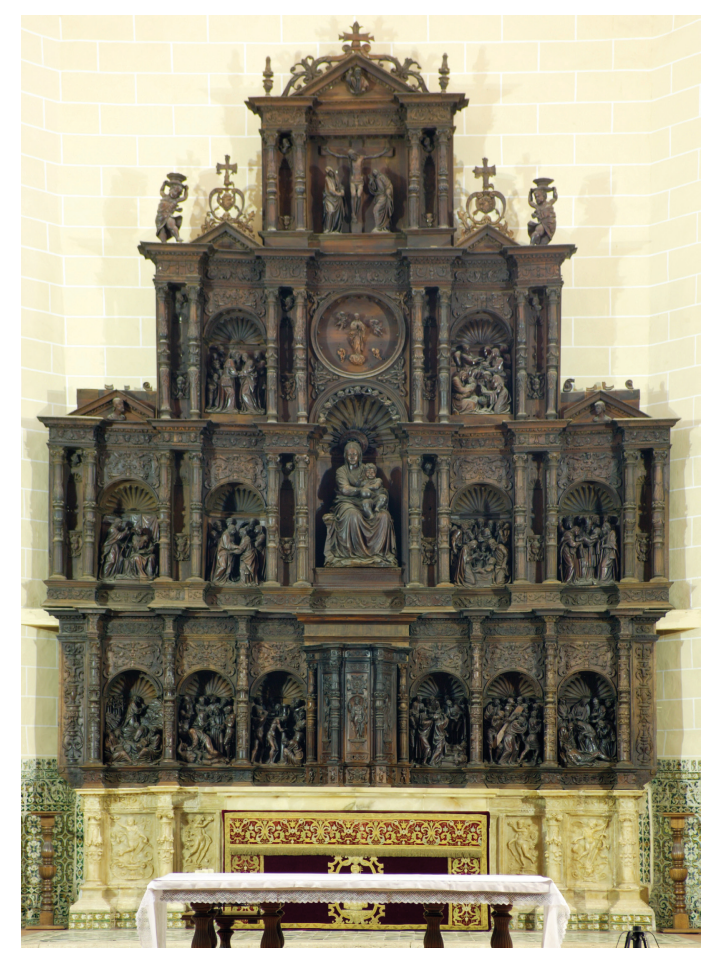

- Fig. 9. Esteban de Obray y Gabriel Joly (atribuido a). Retablo mayor de Nuestra Señora del Castillo de Aniñón. Hacia 1525-1530. Foto José Latova para ASF Imagen.

Como hemos visto, los datos de archivo acreditan que Leveque trabajó para Forment en Zaragoza (1528-1529) y para Obray en Cintruénigo (1530-1531), con seguridad desde Tudela, pero informan igualmente de que Joly le adeudaba 37 ducados viejos y 1 real castellano, lo que debe ocultar alguna colaboración profesional con el picardo, tal vez en el retablo del Museo del Palacio Decanal. Por otra parte, en la documentación generada por la participación de Leveque en el re- 
tablo del obispo de Lérida está presente Joly, que firmó como testigo junto a Peñaranda en la subcontrata; además, tras liquidar sus honorarios por este trabajo y rubricar una comanda con Forment, Leveque delegó en Joly y Peñaranda su cancelación.

Las noticias conocidas sobre el retablo del obispo Conchillos nos llevan a pensar que Joly actuó en este encargo como valedor, aunque no como fiador legal, de su compatriota ante Forment, sin duda porque conocía sus capacidades profesionales, pero sin tampoco descartar que el gesto respondiera a una suerte de solidaridad nacional para facilitar la incorporación al mercado de un recién llegado a quien suponemos con dificultades para manejarse en una lengua que no dominaría. Contamos con más testimonios de este tipo de conducta.

Antes de fallecer en Teruel (en marzo de 1538), Gabriel Joly dispuso un legado testamentario de 2200 sueldos jaqueses en favor de su madre que dos años después Juan Leclert, "tabernero de Varipont de la parrochia de Apilli en la diocesis de Noyon", en calidad de procurador de Jacobina, hermana del escultor, recibió en Zaragoza por manos de Martín Iniesta, yerno del difunto ${ }^{47}$. A continuación, Pierres del Fuego (doc. 1529-†1566), uno de los escultores franceses con taller en Tarazona, se obligó a Martín de Iniesta en una comanda de 1400 sueldos jaqueses que, como se especificó en contracarta, serviría como aval frente a futuras demandas de otros posibles beneficiarios ${ }^{48}$. No hay, pues, duda de que el maestro Pierres, oriundo de Beauvais (Normadía) ejerció de mediador $-\mathrm{y}$, quizás, de traductor- entre las partes $\mathrm{y}$ había dado palabra a Iniesta de que Leclert representaba los intereses de los herederos legítimos de Joly.

\footnotetext{
${ }^{47}$ Abizanda Broto, Documentos..., T. II, 107.

${ }^{48}$ La segunda parte del documento en Javier Ibáñez Fernández, Arquitectura aragonesa del siglo XVI. Propuestas de renovación en tiempos de Hernando de Aragón (15391575) (Zaragoza: Institución "Fernando el Católico", 2005), 375 y 499, n. 27.
}

También nos han llegado algunos datos vinculados a la liquidación de la herencia de Leveque, que tras la celebración de su almoneda recibió en depósito Obray. El 11 de mayo de 1539 el notario real Lope de Gurrea pidió a Juan Navarro, notario público y comisario de las notas del difunto Luis Navarro, que le librara copia de la escritura de comanda que habían pactado diez años atrás Damián Forment y Guillemín Leveque, indicando que procedía a ruegos de Jaime Leveque, hermano de maestre Guillemín, y dando seguridad de que nadie más con derecho sobre sus bienes volvería a requerirle la escritura. Todo sucedió en presencia de Obray, que suscribió el documento indicando "que no bendra a demandar lo sobredicho" ${ }^{\prime 4}$.

Imaginamos que para entonces Jaime Leveque ya había percibido de Obray los 50 florines 10 groses y 8 cornados que devengó la subasta de los bienes de su hermano, y que también le habría puesto en contacto con los deudos de Joly para que le satisficieran lo que le adeudaba el picardo, pero no lo hemos podido acreditar. Lo que sí sabemos es que unas semanas después, el 26 de junio de 1539, Jaime Leveque "pastelero, natural de Todrun del obispado de Cartos -sic- del reino de Francia" ${ }^{50}$, en su nombre y en el de

49 Morte García, Damián Forment..., ap. doc., 493494 , doc. 444 .

${ }^{50}$ El notario no supo trasladar el nombre del obispado, que quizás fuera Cahors, en cuyo caso la inexistente "Todrun" podría ser Gourdon. Agradezco la amable ayuda del Dr. Guy-Michel Leproux, Directeur d'Études de l'École Pratique des Hautes Études de París, en la interpretación del documento.

Cuando Guillemín Leveque recibió de manos de Forment las 90 libras que le adeudaba por su intervención en el retablo del obispo de Lérida, no sólo rubricó la comanda ya mencionada, seguida de la nominación de Joly y Peñaranda como sus representantes para su liquidación, sino que acto seguido, designado como "Guillemin del cabo de la Puent, habitante en Caragoça, natural de la villa de Nay de la Señoria de Bearne", nombró procuradores a pleitos a los notarios Martin Dozta y Miguel del Frasno. En Archivo Histórico de Protocolos de Zaragoza (AHPZ), Protocolo de Luis Navarro, 1529, ff. 312v.-313r. (Zaragoza, 18 octubre de 1529). Nuestro entallador procedía, pues, de la localidad bearnesa de Nay, en el departamento de Pyrénées-Atlantiques. 
sus hermanos Cristóbal, Bárbara y Pedro Leveque, cobró, por fin, de Forment los 756 sueldos que éste debía al difunto entallador -aquí calificado de "imaginero"- en virtud de la tantas veces citada carta de comanda, formalizada el 18 de octubre de 1529 ante Luis Navarro. Como en el caso anterior, el pagador obtuvo garantías de que nadie le reclamaría de nuevo la suma, para lo que el mercader francés designó como fiadores a Lope de Gurrea y Nicolás de Lobato, sin duda el entallador homónimo ${ }^{51}$.

\section{BIBLIOGRAFÍA}

Abizanda Broto, Manuel. Documentos para la historia artística y literaria de Aragón procedentes del Archivo de Protocolos. Siglo XVI. Zaragoza: Patronato Villahermosa-Guaqui, T. I, 1915, y T. II, 1917.

Amada Sanz, Salvador. "Estudio histórico-artístico de la portada y puertas de la Colegiata de Sta. María de Calatayud". BSEE, LI (1947), 177-209.

Arias Martínez, Manuel. “Testamento, inventario y almoneda del ensamblador normando Guillomo Peral (†1591): datos para la definición profesional". Astorica, 28 (2009), 227-253.

Barrón García, Aurelio Á. “Orígenes, formación y testamento del escultor renacentista Arnaut Spierinck, o Arnao de Bruselas". Santander. Estudios de Patrimonio, 2 (2019), 65-120.

Castro, José R. Cuadernos de Arte navarro. B) Escultura. Pamplona: Institución Príncipe de Viana, 1949.

Criado Mainar, Jesús. “Las artes plásticas del Primer Renacimiento en Tarazona (Zaragoza). El tránsito del moderno al romano". Toriaso, X, II (1992), 387-452.

51 AHPZ, Protocolo de Juan Navarro, 1539, ff. 148v.149v. (Zaragoza, 26 de junio de 1539). El documento expresa que Guillemín había fallecido ab intestato. Una parte del contenido se menciona, sin aportar su cota de archivo, en Morte García, "Estudio histórico-artístico...", 30 .
Criado Mainar, Jesús. "Baltasar de Arrás (1536-1543) y la escultura contemporánea en el área del Moncayo". Revista del Centro de Estudios Merindad de Tudela, no 5 (1993), 71-96.

Criado Mainar, Jesús. El Renacimiento en la Comarca de la Comunidad de Calatayud. Pintura y escultura. Calatayud: Centro de Estudios Bilbilitanos de la Institución "Fernando el Católico"-Comarca Comunidad de Calatayud, 2008.

Criado Mainar, Jesús. "Relaciones entre la Ribera de Navarra y Aragón durante la época del Renacimiento". Cuadernos de la Cátedra de Patrimonio y Arte Navarro, no 3 (2008), 213-254.

Criado Mainar, Jesús. "El retablo del Crucificado del Museo del Palacio Decanal de Tudela". En Cátedra de Patrimonio y Arte Navarro. Universidad de Navarra. Memoria 2011, 269-272. Pamplona: Universidad de Navarra, 2011.

Criado Mainar, Jesús. “El Renacimiento en la Catedral". En La Catedral de Santa María de la Huerta de Tarazona, 156-193. Zaragoza: Diputación de Zaragoza, 2013.

Criado Mainar, Jesús y Olga Cantos Martínez. El retablo mayor de Santa María de Olvés. Las claves del Renacimiento en la Comarca de la Comunidad de Calatayud. Calatayud: Centro de Estudios Bilbilitanos de la Institución "Fernando el Católico", 2018.

Dávila Corona, Rosa María, Montserrat Durán Pujol y Máximo García Fernández. Diccionario histórico de telas y tejidos. Salamanca: Junta de Castilla y León, 2004.

Domínguez Bordona, José. “El escultor Felipe Vigarny o de Borgoña (datos inéditos)". BSEE, XXII (1914), 263-266.

Echeverría Goñi, Pedro L. "Protagonismo de los maestros galos de la talla en la introducción y evolución del Renacimiento en Navarra". Príncipe de Viana, LXXIII, no 256 (2012), 515-548. 
Flor, Pedro. “Gelsa e Sintra: relacões artísticas entre Aragão e Portugal no tempo do Renascimento". En El alabastro. Usos artísticos y procedencia del material, coordinado por Carmen Morte García, 201-220. Zaragoza: Prensas Universitarias de Zaragoza, 2018.

García Gainza, María Concepción. “La introducción del Renacimiento. Un brillante promotor y un mecenas". En La catedral de Tudela, 262-285. Pamplona: Gobierno de Navarra, 2006.

García Gainza, María Concepción. "La sillería del coro". En Tudela. El legado de una catedral, 219-220. Pamplona: Fundación para la Conservación de Patrimonio Histórico de Navarra, 2006.

González Mena, María Ángeles. Colección pedagógico textil de la Universidad Complutense de Madrid. Estudio e inventario. Madrid: Editorial Complutense, 1994.

Grilo, Fernando Jorge Artur. “Nicolau Chanterene e a influência italiana na escultura do Renascimento em Portugal. Fontes e práticas artísticas". En El modelo italiano en las artes plásticas de la Península Ibérica durante el Renacimiento, coordinado por María José Redondo Cantera, 393-422. Valladolid: Universidad de Valladolid, 2004.

Hernansanz Merlo, Ángel. "Materiales y técnicas de la escultura". En La escultura del Renacimiento en Aragón, coordinado por María Isabel Álvaro Zamora y Gonzalo M. Borrás Gualis, 57-63. Zaragoza: Museo "Camón Aznar", 1993.

Hycka Espinosa, Olga. Santa María la Mayor y del Pilar de Zaragoza. Evolución histórica del templo colegial. Zaragoza: Institución “Fernando el Católico", 2018.

Ibáñez Fernández, Javier. Arquitectura aragonesa del siglo XVI. Propuestas de renovación en tiempos de Hernando de Aragón (15391575). Zaragoza: Institución "Fernando el Católico", 2005.
Ibáñez Fernández, Javier. "Sculpteurs français en Aragon au XVI ${ }^{\mathrm{e}}$ siècle: Gabriel Joly, Esteban de Obray \& Pierres del Fuego". En La sculpture française du XVI siècle. Études et recherches, editado por Marion Boudon-Machuel, 126-137. París: Institut National d'Histoire de l'Art-Le bec en l'air éditions, 2011.

Miñana Rodrigo, María Luisa, Fernando Sarriá Abadía, Raquel Serrano Gracia, Rosalía Calvo Esteban y Ángel Hernansanz Merlo. "Aportaciones al estudio de la obra de Esteban de Obray en Calatayud". En Segundo Encuentro de Estudios Bilbilitanos. Actas, T. I, 387-395. Calatayud: Centro de Estudios Bilbilitanos de la Institución "Fernando el Católico", 1990.

Morte García, Carmen. "Historia”. En Carmen Morte García, Javier Latorre Zubiri y Clara Fernández-Ladreda Aguadé. El retablo mayor de la iglesia de Santa María la Real de Olite. Historia y conservación, 13-123. Pamplona: Gobierno de Navarra, 2007.

Morte García, Carmen. Damián Forment. Escultor del Renacimiento. Zaragoza: Caja Inmaculada, 2009.

Morte García, Carmen. "Estudio histórico-artístico de una obra renacentista". En Carmen Morte García y Javier Latorre Zubiri. El retablo mayor de la parroquia de San Juan Bautista de Cintruénigo. Historia y conservación, 11-78. Pamplona: Gobierno de Navarra, 2009.

Parrado del Olmo, Jesús María. Talleres escultóricos del siglo XVI en Castilla y León. Arte como idea. Arte como empresa comercial. Valladolid: Universidad de Valladolid, 2002.

Pereda, Felipe. "Adiosdado de Olivares, o la dignidad de las artes mecánicas". En El modelo italiano en las artes plásticas de la Península Ibérica durante el Renacimiento, coord. por María José Redondo Cantera, 291-314. Valladolid: Universidad de Valladolid, 2004. 
Redondo Cantera, María José. “L'apport français à la sculpture de la Renaissance en Castille. Réflexions sur le style et les matériaux". En La sculpture française $d u$ $X V I^{e}$ siècle. Études et recherches, ed. por Marion Boudon-Machuel, 138-149. París: Institut National d'Histoire de l'Art-Le bec en l'air éditions, 2011.

Río de la Hoz, Isabel del. El escultor Felipe Bigarny (h. 1470-1542). Salamanca: Junta de Castilla y León, 2001.

San Vicente, Ángel. Lucidario de Bellas Artes en Zaragoza: 1545-1599. Zaragoza: Real Sociedad Económica Aragonesa de Amigos del País, 1991.

Sanz Artibucilla, José María. “El maestro entallador Pierres del Fuego. Sus primeros oficiales y obras en Navarra". Príncipe de Viana, XV (1944), 145-158.

Sanz Artibucilla, José María. "El maestro entallador Pierres del Fuego. Tragedia familiar y últimas obras en Navarra". Príncipe de Viana, XVII (1944), 329-338.

Serrano Gracia, Raquel. “Obray, Esteban de". En La escultura del Renacimiento en Aragón, coord. por María Isabel Álvaro Zamora y Gonzalo M. Borrás Gualis, 256260. Zaragoza: Museo "Camón Aznar", 1993.

Serrano Gracia, Raquel. "El retablo mayor de Aniñón". Documentos y notas. Armantes, I (1994), 5-47.

Serrano, Raquel, Rosalía Calvo, Ángel Hernansanz, María Luisa Miñana, y Fernando Sarriá. "Gabriel Joly y la corriente escultórica francesa". En Actas del V Coloquio de Arte Aragonés, 113-128. Zaragoza: Diputación General de Aragón, 1989.

Souto Silva, Ana I. "Biografía del escultor Damián Forment". En El retablo mayor de la Basílica de Nuestra Señora del Pilar de Zaragoza, XVII-LV. Zaragoza: Fundación Nueva Empresa-Gobierno de Aragón, 1995.

Turcat, André. Etienne Jamet alias Esteban Jamete. Sculpteur français de la Renaissance en
Espagne condamné par l'Inquisition. París: Picard, 1994.

\section{APÉNDICE DOCUMENTAL}

1

1531, febrero, 15; marzo, 5 y 10. Tudela

Inventario de los bienes que pertenecieron al difunto mase Guillemyn de Baqua, entallador, vecino que fue de Tudela (Navarra), efectuado a instancias de Juan de Corella, teniente de alcalde de la dicha ciudad. A continuación, se efectúa almoneda de dichos bienes, que quedan en manos de maestre Esteban, entallador, vecino de Tudela.

Archivo Municipal de Tudela, Sección de protocolos notariales, Juan Pérez de Añorbe, notario de Tudela, 1531, nํ 206.

Anyo del Nacimiento de Nuestro Señor Jesucristo de mil quinientos trenta un anyo, a quinze dias del mes de febrero, en la ciudat de Tudela.

Por mandado del magnifico Juan de Corella, licenciado, teniente de alcalde por vos, [entre líneas: el noble Luys Diaz d'Armendariz, alcalde y juez ordinario de la dicha ciudat], rogado yo, el infrascripto notario, [efectué] el infrancristo [sic] inbentario [de los bienes] que fueron de mase Guillemyn [tachado: la] Baqua, defunto, entallador, que murio en la ciudat de Tudela. Los quales bienes se allaron en casa del quondam Anton de Alcate, en la perroquia de San Jorge, que afrentan con [ca]sas de los herederos de Juan de Segura, con casas de Miguel d'Oriz, secretario y con la calle publica. Que se allaron los bienes siguientes.

Primo un jubon morado de raso de poco precio.

Item un sayon de Contray, las mangas picadas, raydo.

Item un punyal dorado con sus bolsas y cuchilla.

Item una capa de Contray con trepas de terciopelo guarnecida.

Item unas calcas de Contray picadas.

Item una capa de pardillo y un sayon, el qual dizen se bendio en doze florines de moneda. 
Item una gorra negra.

Item un goante de malla.

Item un broquel y un casco.

Item onze imaygenes de piecas de plomo.

Item doze piecas de fierro con sus mangos de fusta de su oficio, y un martillo, y unas lecas y dos barrenicas.

Item un albaran de veinteseis ducados a un cabo, siete reales, y por otra parte en el mesmo ocho ducados viejos y seis sueldos, y mas tres ducados. Que [e]s todo el dicho albaran trenta y siete ducados y diez reales castellanos.

Los quales bienes tenia enbentariados el padre fray Juan Dyego de Imiguitu, goardian del conbento de San Francisco de la ciudat de Tudela, estando presentes al dicho inbentario coando el dicho fray Diego de Imiguitu [los] recebio Joan Fernandez, testigo, y Anton d'Alcate [tacahado: los quo], Oliber de Santribuen y Juan de Baygorri. Los quales bienes se an allado de presente en casa de la biuda del quondam Anton d'Alcate y los conoce tener de manifiesto [abreviatura] masse [sobrescrito: Steban].

Item catorze fresos del oficio, un escofia, mas una espada. Todo lo susodicho esta en poder de mase Steban, entallador, los quoales conocio y se obligo con su persona y bienes a dar cuenta dellos toda y coando le sea mandado.

Asimismo se allo en el inbentario echo por el dicho padre fray Diego de Imiguitu que se allaron en contados diziseis ducados biejos, los quoales recebio Anton d'Alcate, difunto, y destribuyo lo siguiente por mano del dicho padre fray Diego:

Primo coatro baras de tela para la mortaja costaron veinte tarjas. XX tarjas.

Item por lebar el cuerpo i fazer la sepultura seis tarjas. VI tarjas.

Item mas la cera y solera ocho tarjas y media. VIII tarjas media.

Item mas dia al moço seis tarjas. VI tarjas.

Item pague al especiero por las medicinas doze reales nabar[r]os. XXXVI tarjas.
Item pague al medico doze reales tabarros. XXXVI tarjas.

Item pague por una misa cantada para [e]l enterrorio coatro tarjas. IIII tarjas.

Item pague a los capellanes de Santa Maria para conpanyar el cuerpo seis tarjas. VI tarjas.

Item pague por las canpanas de Santa Maria dos tarjas. II tarjas.

Item pague a la canpana de San Francisco una tarja. I tarja.

Item [tachado: pague] di a su criado Oliber para que fuese a Calatayut a mastre Esteban, entallador, un ducado biejo. $1 \mathrm{du}$ cado.

III ducados XXXXV tarjas media.

Estan doze ducados biejos y coatro tarjas y media.

La demasia y bienes en este inbentario fueron encomendados a mastre Esteban, entallador, vecino de Tudela, el quoal asi conocio tenerlos encomendados y dar dellos cuenta. Testigos de la encomienda [ $t a-$ chado: mas] el padre fray Diego Imiguillo y mase Oliber, entallador. En fe y testimonio de berdat firme yo, el notario, y padre fray Diego Amiguillo y firmo mase Steban como tenedor dellos.

[Suscripciones autógrafas: Frai Didacus de Imiguitu.

Yo, maestre Steuan.

Notario Joan Periz de Añorbe].

Estan manifestados que debe mase Forment, vezino de Caragoca, al dicho mase Guillemin de Baqua, difunto, coarenta libras jaquesas.

Anyo del nacimiento de Nuestro Señor Jesucristo de mil y quinientos y trentaun año, a cinco dias del mes de marco, en la ciudad de Tudela, fue echo almanoneda [sic] de los dichos bienes en este inbentario contenidos que fueron del dicho mase Guillemin de Baqua, difunto, con licencia de Joan de Corella, licenciado, teniente de alcalde por Luys Diaz d'Armendariz. Se bendyeron los bienes seguientes:

Primo se remato un par de calcas negras a Pedro el tondidor por beinteocho tarjas. 
Item al mesmo las ferramientas todas en el inbentario contenidas en cincuenta y coatro tarjas.

Item un sayo a Joan Perez de Añorbe por beinteun real nabarro.

Item a Pedro el tondidor la capa goarnecida se remato por doze florines de moneda.

Item al moco de Jayme de Tornamira un jubon de raso pasado biejo nuebe tarjas y media.

Item al mesmo un punyal dorado por trenta tarjas.

Item al mesmo una gor[r]a negra rayda por beinteuna tarja.

Que montan estas partidas del almoneda desta media plana trezientas y sesenta y cinco tarjas y media.

Item una scofia bieja por cinco tarjas al mesmo. $\mathrm{V}$ tarjas.

Item una caxa por quinze tarjas al mesmo. XV tarjas.

Item una spada a Goan Castillo por XXXXII tarjas. XXXXII tarjas.

Item un casco por seis tarjas. VI tarjas.

Todo lo sobredicho fue encomendado a mase Steban, entallador, vecino de Tudella.

Suma esta otra plana de atras trenta dos florines y diez groses.

Suma esta presente seys florines ocho cornados.

Suma el sayo primero y capa que se bendio doze florines, de manera que monta lo que se a bendido de los bienes del dicho masse Guillemin de Baqua, defuno, a menos de las deudas que por los albaranes se le deben, cincuenta florines diez groses ocho cornados, los quales el dicho mase Steban conocio aberlos recebido de contados en su poder y como depositario de corte se obligo con su persona y bienes de restituir y dar los dichos cincuenta florines de moneda del almoneda, y el albaran de los trenta y siete ducados biejos y un real castellano que debe mase Gabriel, ymaginario, vezino de Caragoca, y mas los seze ducados que al tiempo que murio el dicho mase Guillen de Baqua se allaron, segun parece por el ynbentario, y de darlos y render todos los dichos bienes cada que el señor alcalde de la ciudat de Tudela ho de su teniente en juyzio fuere mandado, obligando su persona y bienes, renunciando su propio fuero y alcalde propio que fue mandado reportar tal acto por el magnifico Joan de Corella, licenciado, teniente de alcalde de la ciudat de Tudela por el magnifico Luys Diaz d'Armendariz, alcalde ordinario de la ciudat de Tudela.

Lo qual fue mandado a diez diaz del mes de marco del anyo de mil y quinientos y trentaun años. Presentes siendo por testigos Pero Lorenz Copin, secretario, y Diego de Frias, notario, vezinos de la ciudat de Tudela, lo qual se izo estando asentado en juicio el dicho teniente de alcalde en las casas de la ciudat de Tudela.

El dicho mase Steban de [espacio en blanco para una palabra], entallador, lo firmo conosxendo tenerlo todo lo susodicho en deposito, y lo mando el dicho teniente reportar por mi, el dicho notario.

[Suscripciones autógrafas: Io, maestro Esteuan.

Notario Joan Periz d'Añorbe]. 